\title{
Resistance of Flat Plate Reinforced of Glass Fiber Mesh Sheets Due To Shear Punching
}

\author{
Mohamed S. Moawad
}

\begin{abstract}
: punching shear failure of the flat plat of the column location especially of two-way flat plat is one of the major problem and this form of failure should be avoided. The paper deals with the punching shear behavior of the two-way concrete slabs reinforced by using thin sheets of glass fiber reinforced polymer (GFRP) with traditional steel bars reinforcement. Five flat plat specimens slabs measuring $(1500 \times 1500 \times 150 \mathrm{~mm})$ with interior column measuring (150mmX150mm). Reinforced by GFRP thin mesh sheets in additional of deformed steel bars reinforcement were conducted and tested under concentric load until failure. The test parameter were studied i) No. of GFRP thin mesh sheets layers ii) Position of GFRP mesh thin sheets layers (at compression and tension zones). The test results were reported in terms of cracking behavior and propagation, maximum deflection, strains in concrete and reinforcement, punching shear capacity, and modes of failure. The test results were also employed to assess the accuracy of the available punching shear capacity equations including the new punching equations in ECP2018.201. The test results show that increasing in the punching shear capacity, decreasing of the average cracking widths, and improving in an integrity of the slab specimens which reinforcing by glass fiber thin mesh sheets in the post cracking stage in comparison with conventional reinforced concrete slabs.
\end{abstract}

KEYWORDS; Glass Fiber-reinforced concrete; Flat plat; Punching shear resistance; Concrete slabs; fabric mesh ; Cracking behavior.

\section{INTRODUCTION}

$\mathbf{P}$ unching shear is a type of brittle failure of flat plates. The major concern when using flat plates is shear transfer from the slab to the columns. In other words, there is a danger that columns may punch through the slab. especially, the most of flat plat failure are against to shear punching when shear punching stresses of the plat flat connection are exceed of flat plat capacity against punching shear especially the small thicknesses of flat plat Although the shear punching can be relieved by localized thickening of the concrete with down stand. so; in this research is studied that the contribution of glass fiber mesh sheets as an additional reinforcement with ordinary steel bars reinforcement of flat plates at localized column "maximum shear punching stresses" without increasing of its flat plates thickness to resist of punching shear stresses. Normally, the stresses resulting from the two-way shear are much higher than the resulting from the one-way shear.

Revised Manuscript Received on April 25, 2020.

* Correspondence Author

M.s. Moawad*, structural department, future high institute of engineering, Fayoum, Egypt. M.moawad@fief.edu.eg

(C) The Authors. Published by Blue Eyes Intelligence Engineering and Sciences Publication (BEIESP). This is an open access article under the CC BY-NC-ND license (http://creativecommons.org/licenses/by-nc-nd/4.0/)
And the conventional reinforcement of shear by means of headed shear studs ${ }^{11[}$, shearheads ${ }^{11[}$, and stirrups ${ }^{11,12[,] 3[}$ is applicable only to slabs with the depth greater than $150 \mathrm{~mm}$. So; this research is investigated that the increasing of punching shear capacity in two way flat slab which it have a thickness less than or equal to $150 \mathrm{~mm}$ by using mesh thin sheets of glass fiber adding as an extra reinforcement with traditional steel bars. Most of researchers are concerned that the shear punching failure that can be happen in a flat plate structural member. So; many alternatives to enhance and increase of its ductility behavior were suggested. Previous studies suggested the use of conventional shear reinforcement, shear head steel, shear stud, helix reinforcement, and lattice reinforcement to enhance the punching shear capacity of flat slab structures ${ }^{[9[}$.

The glass fiber mesh sheets that it were reinforced of concrete slabs against punching shear stress are investigated and concluded that the effecting of the fiber mesh to resisting a punching shear stresses is very efficient as reinforcement ${ }^{35}$.

The contribution of FRP-Reinforced two-way flat slabs and steel-reinforced slabs designed are investigated and reported that the all specimens had similar punching shear capacities $^{113}$.

The investigation of the Behavior of flat slab specimens with presence of FRP sheets and steel bolts substantially led to the increasing of the punching capacity of the connections $^{\mathrm{j}}{ }^{7 \mathrm{~L}}$.

The behavior of flat plat with interior column and reinforced by GFRP bars under concentric load. The results of its study can be summarized that the concentrating of the GFRP reinforcement bars in the compression side through the column cross section led to enhance of the overall slab behavior with a slight increasing in the post-cracking stiffness and the ultimate punching shear capacity ${ }^{114[}$.

\section{DESIGN CONCEPT OF SPECIMENS}

\section{A. Design Philosophy Models to Predict of Punching Shear Capacity}

The shear punching capacity of a flat plat that is reinforced by Glass fiber reinforced polymer with conventional deformed steel bars can be considered to comprise two components, that is, the contribution from "Concrete" $V_{\mathrm{RC}}$ and the contribution from "GLASS FIBER REINFORCED POLYMER mesh sheets", $\mathrm{V}_{\mathrm{RF}}$. Several international standards ${ }^{[1,8[}$. generally, 
the value of $\mathrm{V}_{\mathrm{RC}}$ is a function of the tensile strength of concrete (expressed in terms of cylinder compressive strength of concrete, fc') and effective depth (d) to the tensile steel reinforcement. ${ }^{[4,8[}$ also consider $V_{R C}$ to be governed by the reinforcing steel ratio and yield strength of steel reinforcement respectively.

The "GFRP mesh sheets fiber" contribution, $\mathrm{V}_{\mathrm{RF}}$ is primarily expressed as a function of the fiber content and thereby the residual tensile strength of GFRP.

\section{B. Flexural Capacity of GFRP Mesh Sheets Reinforced of Flat Plat under Concentric Load}

The yield line theory has been used with reasonable accuracy to predict the flexural capacity of flat plat reinforced concrete. Figure 1; shows that the indicates two possible yield line patterns for a square simply supported flat plat under a central point load.

The basic yield line pattern as shown in the figure 1.a gives that the failure load, and maximum resistant moment of the flat plat cross section equal to $8 \mathrm{MB}$.

Figure (1.b); shows that the part of fan mode (punching shear failure) yield line pattern which it can be Predicts a failure load equal to $2 \pi \mathrm{MB}$,

One from two the previous methods was used in this research paper of yield line to predict the maximum moment resistance against flexural failure. So; the fan mode (punching shear failure) was used.

a) Basic Pattern

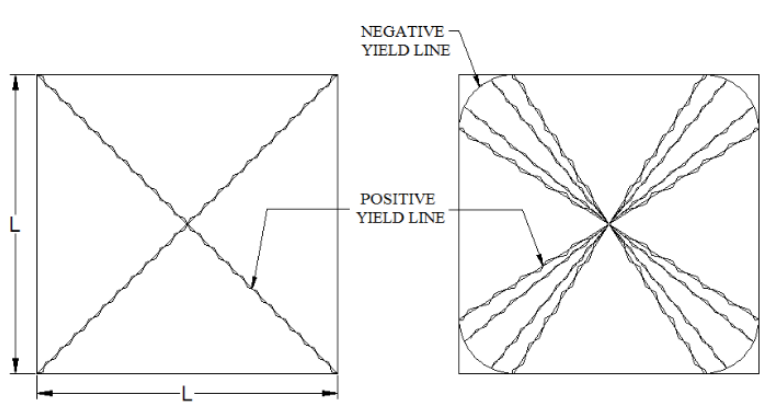

figure 1: yield line patterns

\section{EXPERIMENTAL PROGRAM}

\section{A. Materials Specification}

Materials of test specimen were prepared from available local materials. Concrete mixture was used throughout casting and was designed to develop cube strength of 30MPa. The test program. The water cement ratio was 0.4 . and the slump for the concrete mixture is $60-70 \mathrm{~mm}$. Natural siliceous $\left(0-4 \mathrm{~mm}, 660 \mathrm{Kg} / \mathrm{m}^{3}\right)$ and crushed stone $(9-22 \mathrm{~mm}$, $\left.1194 \mathrm{~kg} / \mathrm{m}^{3}\right)$. Ordinary Portland cement (OPC) $\left(370 \mathrm{Kg} / \mathrm{m}^{3}\right)$ as a binder material. Super plasticizer admixture "high rang water reducing and early strength aid" was used in concrete mixture. The additive was used, Due to lower water demand required, to Decrease the water/binder ratio. Superplasticizer was complies of ASTM C494. Testing of these materials were carried out according to Egyptian standard specifications, and ASTM standards. Deformed high-grade steel bars of $18 \mathrm{~mm}$ diameter with yield strength of 370 $\mathrm{N} / \mathrm{mm}^{2}$ and ultimate strength of $520 \mathrm{~N} / \mathrm{mm}^{2}$ were used as a longitudinal tension reinforcement. Mild steel bars of $8 \mathrm{~mm}$ diameter with yield strength of $240 \mathrm{~N} / \mathrm{mm}^{2}$ was used as stirrups and longitudinal compression reinforcement. Steel bars were tested and complies with Egyptian Standard Specifications and the ASTM standards.

GFRP thin mesh sheet is a unidirectional woven glass fiber fabric and designed to embedded into a two way flat slab (E-glass fibers, area density of fiber $=600 \mathrm{~g} / \mathrm{cm}^{2}$, Dry Fiber Thickness $=0.168 \mathrm{~mm}$, Dry Fiber Tensile Strength $=2$ $500 \mathrm{~N} / \mathrm{mm}^{2}$, Dry Fiber Modulus of Elasticity in Tension = $72000 \mathrm{~N} / \mathrm{mm} 2$, Dry Fiber Elongation at Break= $2.7 \%$ ) were used to reinforced a two way flat slab interior columns at compression or tension zone.

\section{B. Test Specimen Details}

The tested five flat plats specimens have dimensions (1100mmx1100mm). And the centric column dimension is (150mmx150mm) were used to ensure sufficiently high punching shear stresses in the slabs.

The flat plates specimens have a thickness $150 \mathrm{~mm}$ and the conventional deformed bars reinforcement ratio ? $=1.25 \%$ in both principal directions. As the aim of the study is to investigate the effect of thin mesh of glass fiber with traditional tensile reinforcement steel bars to increase the punching shear capacity of the flat plat and column connection, the compression reinforcement was not been used by traditional reinforcement steel bars. And glass fiber thin mesh sheet were laid in compression or tension zone in the flat slab-column connection specimens.

The slabs specimens were conducted due to No. of glass mesh fiber layers and its position and are listed below:-

S1: was just reinforced by traditional steel bars in tension zone (fig.2).

S2: was reinforced by both traditional steel bars with 3layers of thin mesh GFRP sheets in tension zone (fig.3).

S3: was reinforced by both traditional steel bars with 6layers of thin mesh GFRP sheets in tension zone (fig.4).

S4: was reinforced by both traditional steel bars in tension zone with 3-layers of thin mesh GFRP sheets in compression zone (fig.5).

S5: was reinforced by both traditional steel bars with 6layers of thin mesh GFRP sheets in compression zone (fig.6).

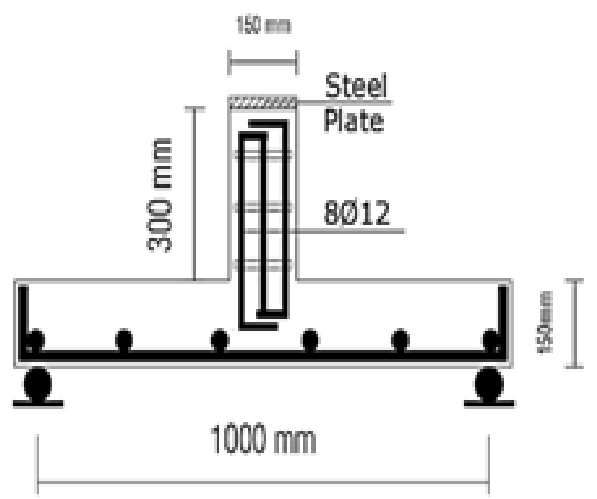

Figure 2: Sample S1

Published By:

Blue Eyes Intelligence Engineering \& Sciences Publication

(C) Copyright: All rights reserved. 


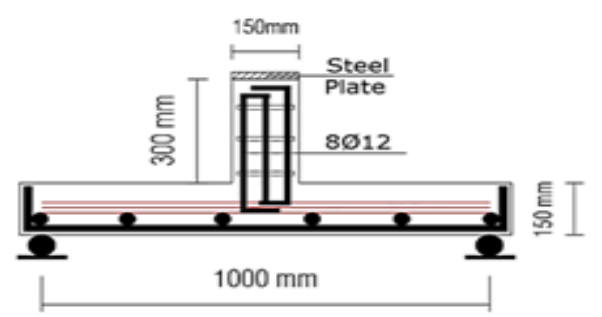

Figure 3: Sample S2

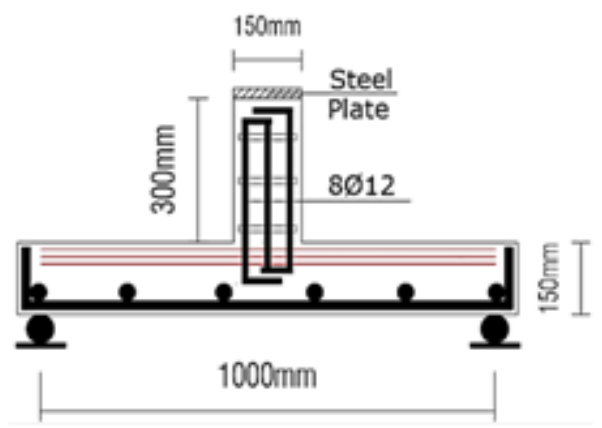

Figure 4: Sample S3

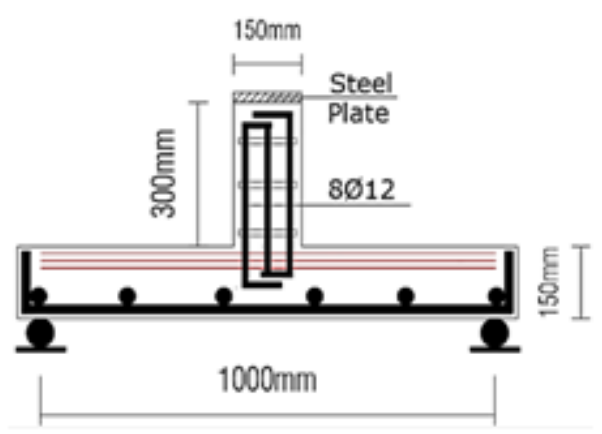

Figure 5: Sample S4

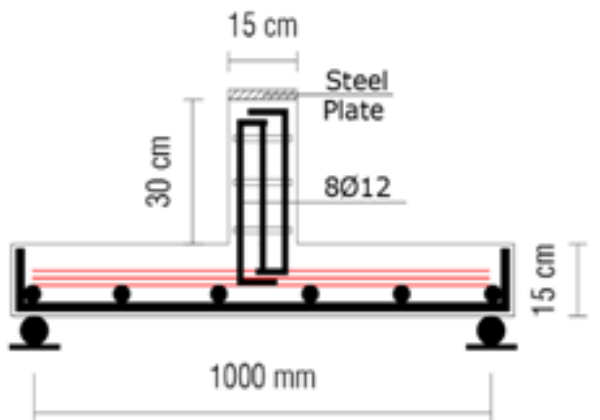

Figure 6: Sample S5

\section{Concrete Mixing, Placing, and Curing}

Clean wood forms were used, and their inner sides were coated with oil before casting. The reinforcement steel was arranged and placed in its proper position in forms as shown in figure 7.

The time of mixing was about three minutes; half minute to mix the dry materials until uniform color is observed immediately. After mixing concrete was placed in the forms and compacted mechanically by internal electrical vibrator considering the proper of reinforcement during casting.
Concrete constituents were batched separately by weight using a mechanical balance of $0.1 \mathrm{Kg}$ sensitivity, while water cement ratio was batched by weight of mixing which performed using a concrete titling drum mixer as shown in figure 8 , and figure 9 .

The compressive strength of hardened concrete were investigated for each flat plat of specimens. At least six standard cubes (150x150x150 mm) were taken. Three cubes were tested after 7 days, and others three cubes were tested after 28 days. They were cast from the same batches used for casting the specimens.

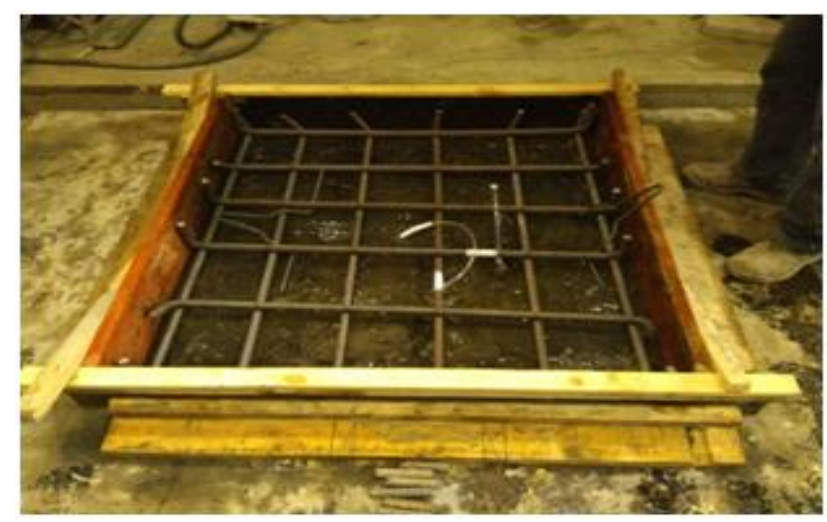

Figure 7: Conventional Steel Bars Reinforcement

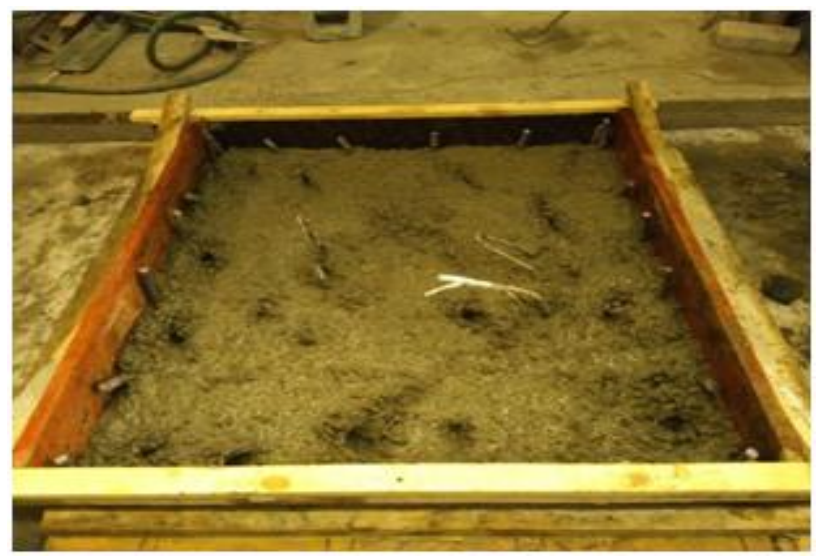

Figure 8: Partial Casting of Concrete into Flat Plat of the Wood Forms

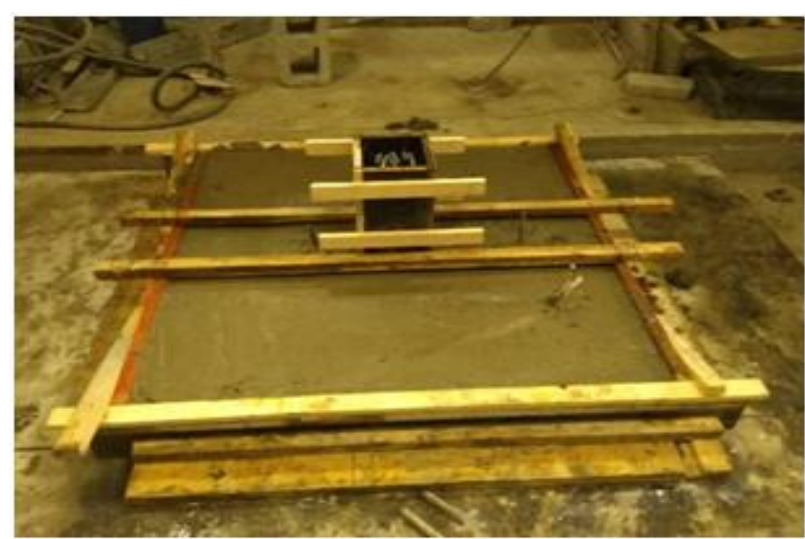

Figure 9: Fully Casting of Concrete into Flat Plat of the Wood Forms

Published By:

Blue Eyes Intelligence Engineering \& Sciences Publication

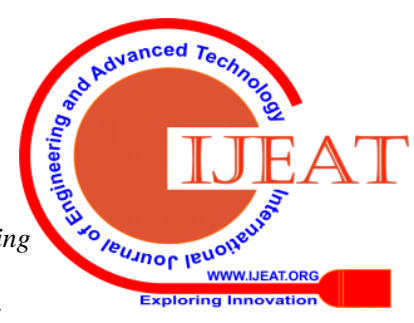




\section{Resistance of Flat Plate Reinforced of Glass Fiber Mesh Sheets Due To Shear Punching}

\section{Test Setup and Instrumentation}

The flat plat specimens were loaded under concentric load, which it applied on the column, and supported, by tie rod until failure as shown in figure 10. The specimens were simply supported along four edges. Three linear variable differential transformers (LVDTs) were used to determine deflections at mid span and at the quarter-span of the slabs as figure 11. Two strain gauges were bonded in two principle directions on the longitudinal tensile rebar. And one gauge on the top surface of the slabs to measure concrete strains figure12. The location of strain gauge for reinforcement is identical with that of strain gauges for concrete approximately $25 \mathrm{~mm}$ from the surface of the column. The slabs were tested by a hydraulic testing machine capacity $1000 \mathrm{KN}$ under the load control in increments of $10 \mathrm{KN}$ up to failure. The loading rate was approximately $12 \mathrm{KN} / \mathrm{min}$. deflections, strain in concrete, strain in steel rebar, and crack development were recorded at each load level.

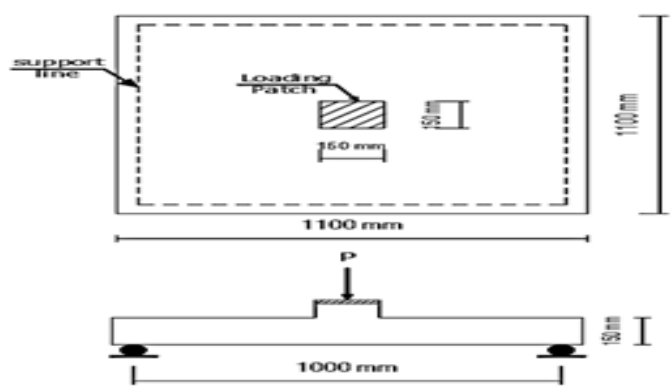

Figure 10: Central Point Load Test on Two-Way SlabColumn Connection

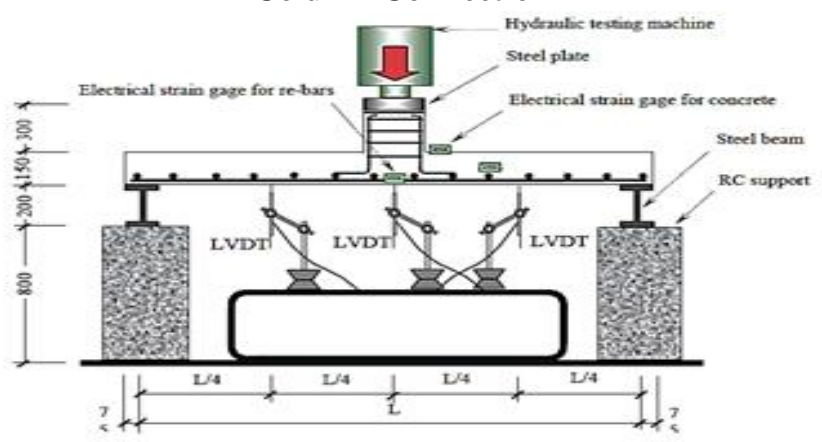

Figure 11: Tested Specimens Details and Test Arrangement

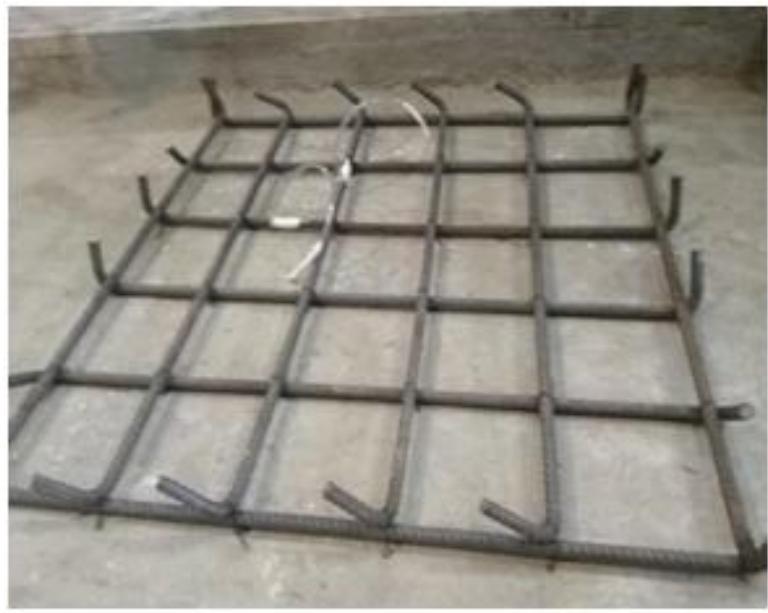

12.a) Strain Gauges of Conventional Deformed Steel Bars Reinforcement

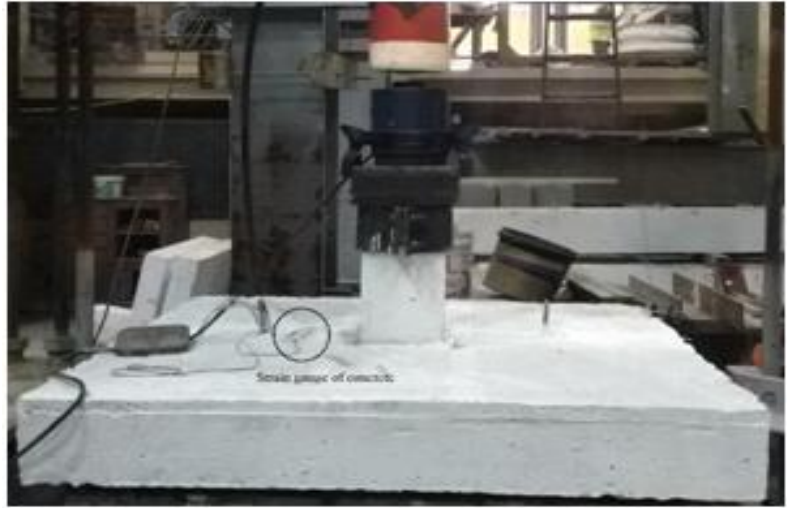

12.b) Strain Gauge of Concrete

Figure 12: Test Slab Arrangement

\section{TEST RESULTS AND DISCUSSION}

\section{A. Cracking and Failure Characteristics}

Generally, at start stage of loading, a micro cracks propagated parallel to the bottom steel reinforcement bars. However, these cracks had not influence on the final type of mode failure with the increase in the applied load; these cracks become wider and propagated in several directions (normally diagonal directions). During applied load time, more cracks occurred and propagated in similar manner as the earlier cracks.

Control slab specimens (S1) was failed in punching shear. The failure of specimen (S1) was occurred suddenly in a brittle manner in the column vicinity and the typical crack pattern on the underside of the slabs is shown in (fig.13).

Remaining specimens, the first cracks to appear in all the tested specimens were flexural radial cracks in the region of the maximum moment in the tension (top side) of the slab. The cracks started at the column, corners parallel to $\mathrm{X}$ and $\mathrm{Y}$-axes there after propagated radially towards the slab edges. At higher loads small cracks appeared at the column interface along the perimeter. Moreover, circumferential cracks were observed near the column connecting the radial cracks together. In these slabs specimen, cracks formed uniformly with smaller average width due to the effect of No. of layers and positions of glass fiber thin mesh sheets in a samples.

Flexural failure with ductile mode can be clearly observed also for these specimens. The thin mesh sheet of glass fiber can be improved significantly concrete ductility and integrity of vicinity of slab-column connection and the typical crack pattern on the underside of the slabs is shown in (figures.14, 15, 16, and 17)

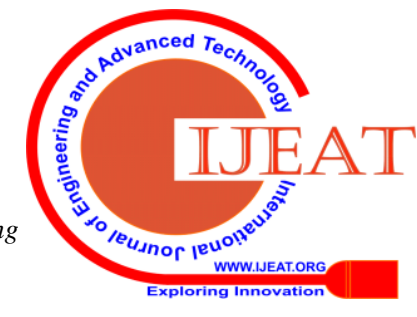




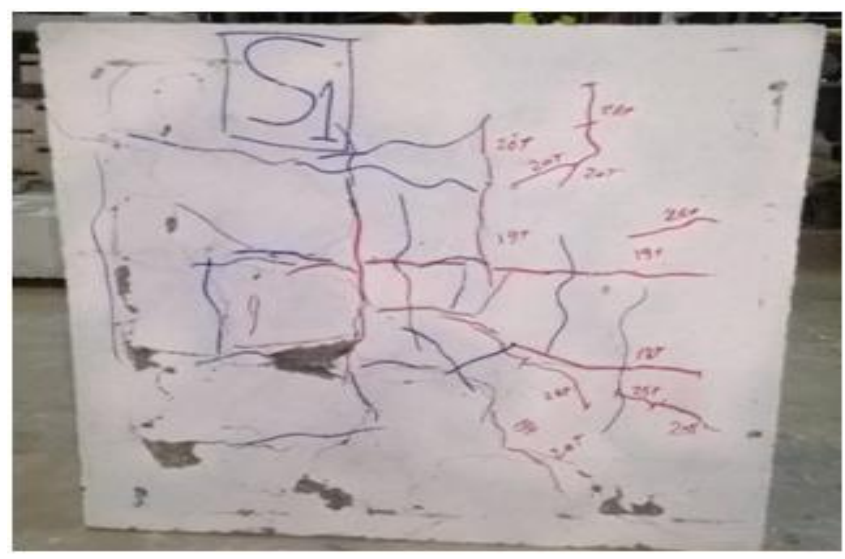

Figure 13: Cracks Propagation of Testing Slab (S1)

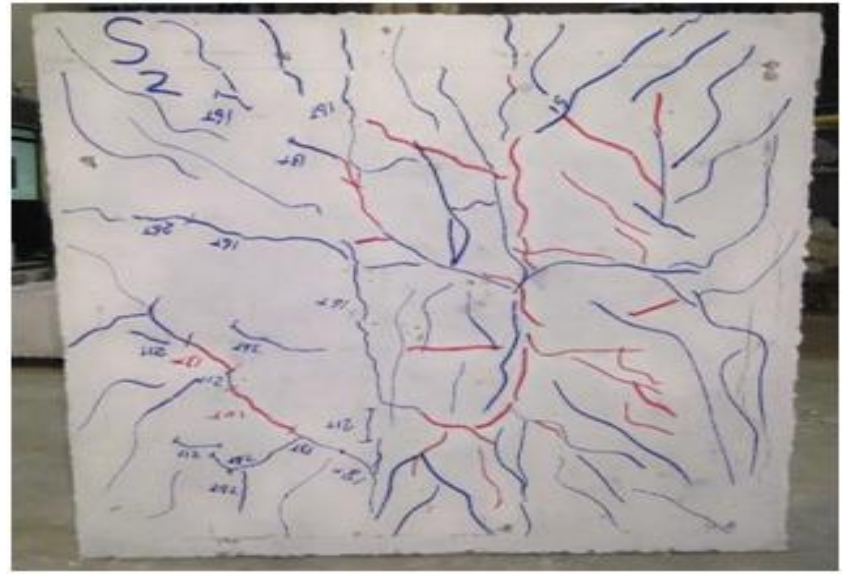

Figure 14: Cracks Propagation of Testing Slab (S2)

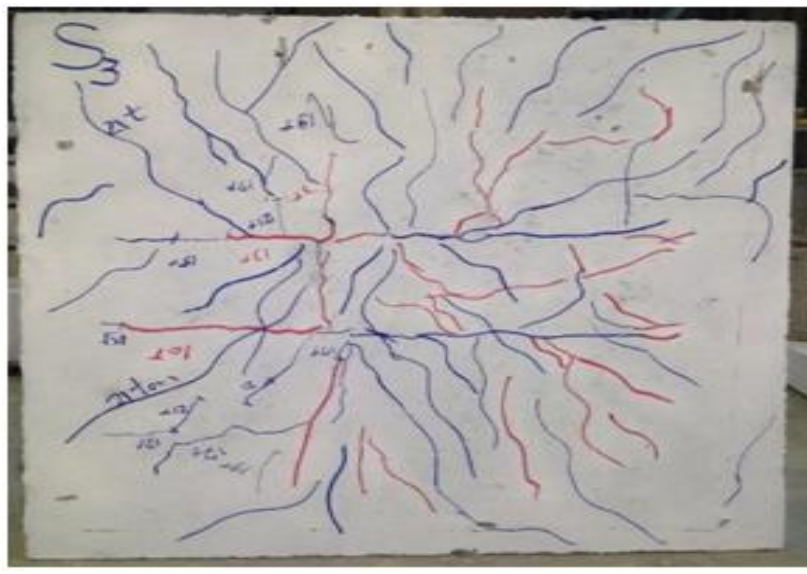

Figure 15: Cracks Propagation of Testing Slab (S3)

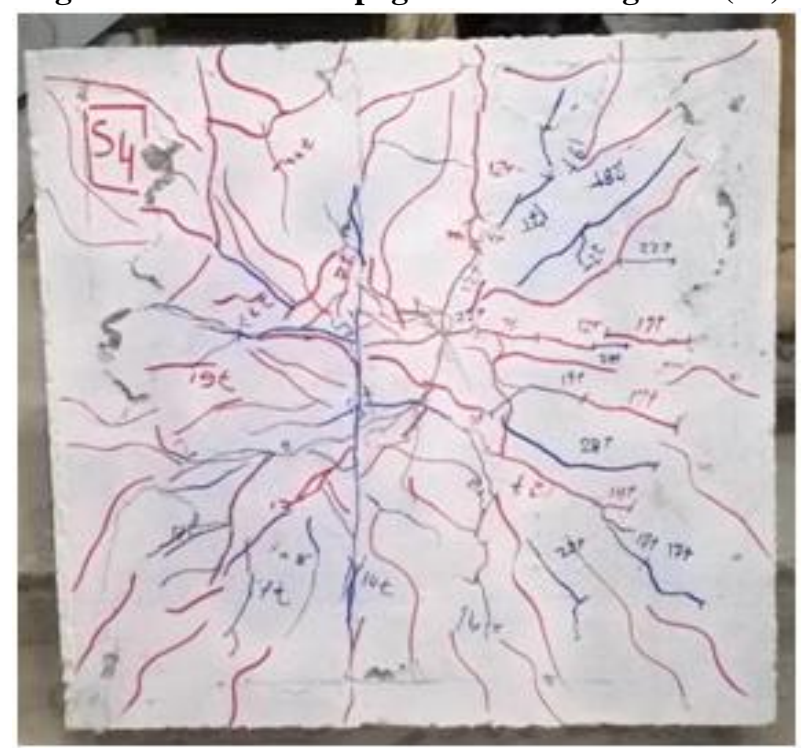

Retrieval Number: D7623049420/2020@BEIESP
Figure 16: Cracks Propagation of Testing Slab (S4)

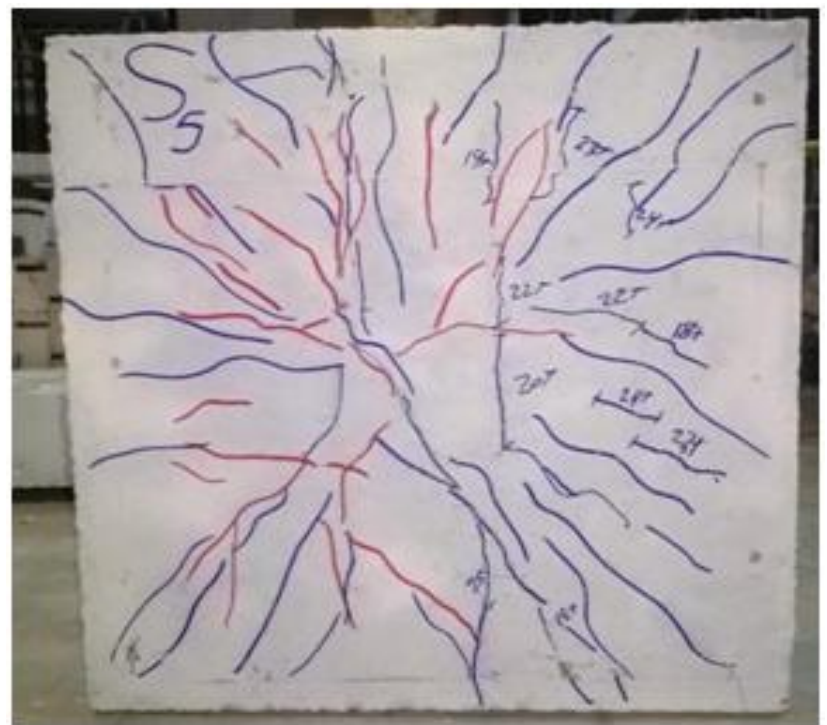

Figure 17: Cracks Propagation of Testing Slab (S5)

B. Load-Displacement Response and Shear Punching

\section{Resistance}

The relative load-displacement diagrams of tested slab specimens are shown in Figure 18. In general, the behavior of slabs can be divided into two stages. The first stage was named "stage prior to crack", in which the behavior of all slab specimens was similar, and was approximately linear. In next stage (post-cracking stage), cracks were initiated and developed, which resulted in decrease of stiffness of the slabs and caused difference in the behavior of the slabs. At the same loading level, displacement of slab specimens S2, S3, S4, and S5 is lower than control slab specimen S1. It means that; thin mesh sheet of glass fiber increasing of slab specimens stiffness and this is directly proportional numbers of thin sheets of glass fiber mesh and its position in the slab. Figure 19, plots the load and the reinforcement strain relationships. This figure uses the strain values recorded from the electrical resistance strain gauges located at 250 $\mathrm{mm}$ from the center of the $150 \mathrm{~mm}$ square columns at the layer of steel. Figure 20, plots the load and the concrete strain relationships. This figure uses the strain values recorded from the electrical resistance strain gauges located at $250 \mathrm{~mm}$ from the center of the $150 \mathrm{~mm}$ square columns on a compression zone of concrete.

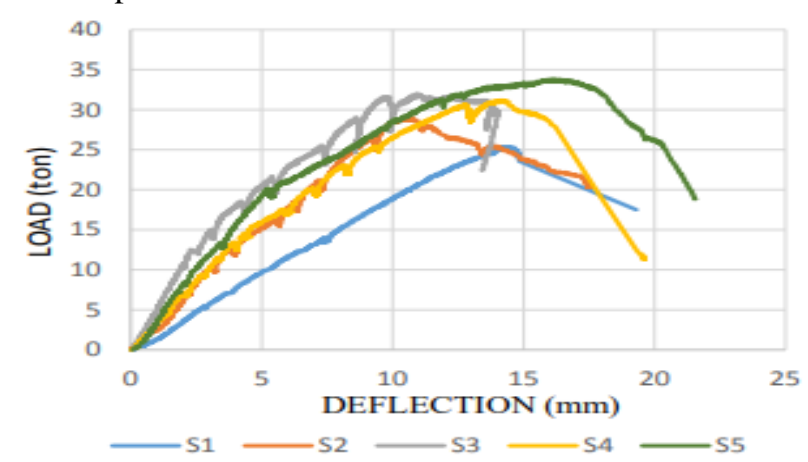

Figure 18: Load-Mid Displacement (Deflection) of Slabs Specimens

\section{Published By:}

Blue Eyes Intelligence Engineering \& Sciences Publication

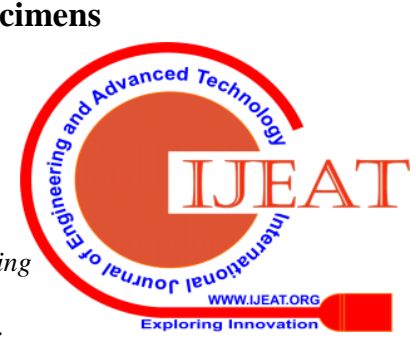




\section{Resistance of Flat Plate Reinforced of Glass Fiber Mesh Sheets Due To Shear Punching}

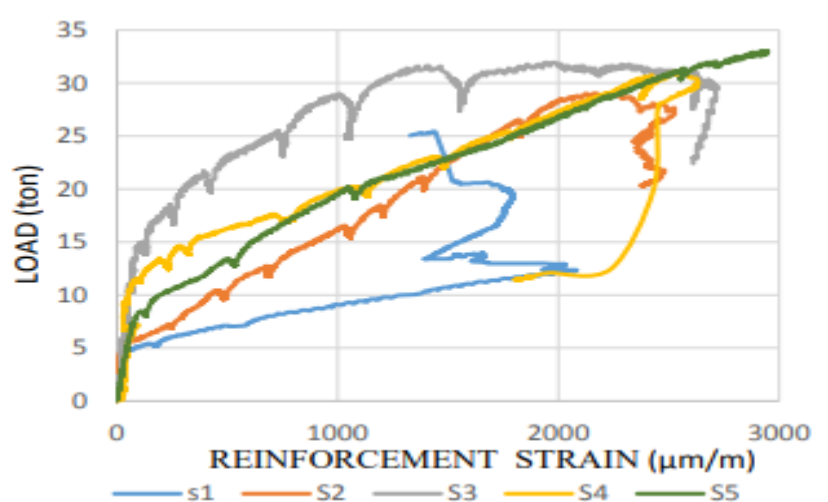

Figure 19: Load-Steel Reinforcement Strain

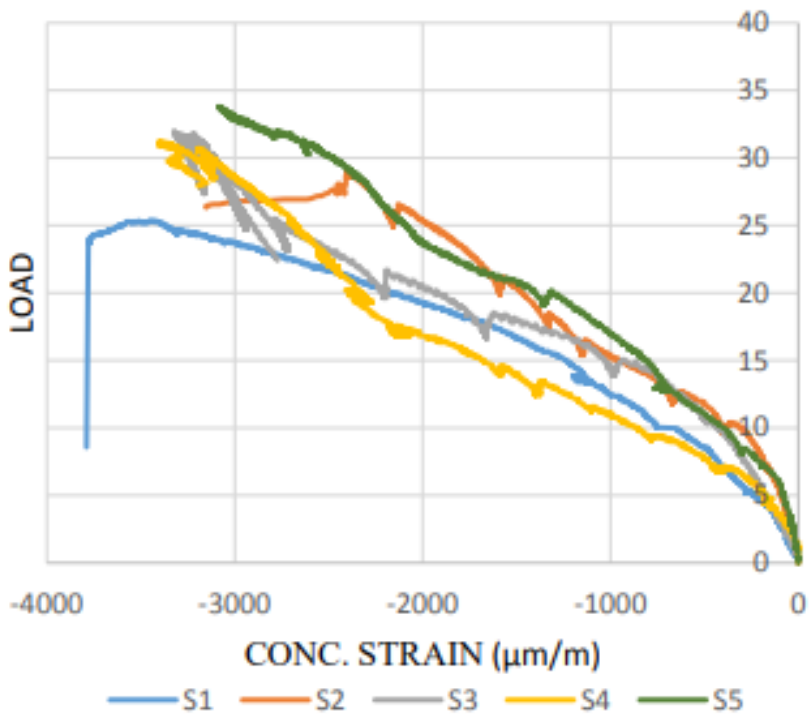

Table 1, and 2 are summarized slab specimens properties and specifications, The failure loads capacity, resistance of punching shear, maximum deflection, parameter study, maximum strain values of concrete and steel, and modes of failures are listed below:-

Tested specimens were divided into two groups as shown in table 3. Each group has an intended purpose for testing as follows;

- Group 1: studied that the effect and contribution of glass fiber mesh sheet volume introduced by increasing in No. of mesh sheets layers with conventional deformed steel bars reinforcement to resist the punching shear of flat plat reinforced concrete.

- Group 2: studied that the effect and contribution of glass fiber mesh sheet reinforced polymer position introduced by lying of mesh sheets layers at tension zone and compression zone with conventional deformed steel bars reinforced to resist the punching shear of flat plat reinforced concrete.

Figure 20: Load-Concrete Strain

\section{SUMMARY OF TEST RESULTS}

Table1: Tested Specimens Details

\begin{tabular}{|c|c|c|c|c|c|c|}
\hline $\begin{array}{c}\text { slab } \\
\text { ID }\end{array}$ & $\begin{array}{l}\text { Dimension } \\
\quad(\mathrm{mm})\end{array}$ & $\begin{array}{c}\text { Slab } \\
\text { thickness } \\
(\mathrm{mm})\end{array}$ & $\begin{array}{l}\text { Effective depth, d } \\
\text { (mm) }\end{array}$ & $\begin{array}{l}\text { Slab flexural } \\
\text { reinforcement }\end{array}$ & $\begin{array}{l}\text { Slab Compression } \\
\text { reinforcement }\end{array}$ & Fiber type \\
\hline S1 & $1100 \times 1100$ & 150 & 125 & $5 \varnothing 18 / \mathrm{m}^{\prime}$ & ------------- & ------------- \\
\hline S2 & $1100 X 1100$ & 150 & 125 & $\begin{array}{c}5 ø 18 / \mathrm{m}^{\prime} \\
+\begin{array}{c}\text { 3-layers of GFRP } \\
\text { sheet }\end{array} \\
\end{array}$ & ------------- & $\begin{array}{c}\text { Thin mesh sheet } \\
\text { of GFRP }\end{array}$ \\
\hline S3 & 1100X1100 & 150 & 125 & $\begin{array}{c}5 ø 18 / \mathrm{m}^{\prime} \\
+ \text { 6-layers of GFRP } \\
\text { sheet } \\
\end{array}$ & ----------- & $\begin{array}{c}\text { Thin mesh sheet } \\
\text { of GFRP }\end{array}$ \\
\hline S4 & $1100 X 1100$ & 150 & 125 & $5 ø 18 / \mathrm{m}^{\prime}$ & $\begin{array}{c}\text { Laying 3-layers of } \\
\text { thin mesh GFRP } \\
\text { sheets }\end{array}$ & $\begin{array}{c}\text { Thin mesh sheet } \\
\text { of GFRP }\end{array}$ \\
\hline S5 & $1100 X 1100$ & 150 & 125 & $5 ø 18 / \mathrm{m}^{\prime}$ & $\begin{array}{l}\text { Laying 6-layers of } \\
\text { thin mesh GFRP } \\
\text { sheets }\end{array}$ & $\begin{array}{c}\text { Thin mesh sheet } \\
\text { of GFRP }\end{array}$ \\
\hline
\end{tabular}

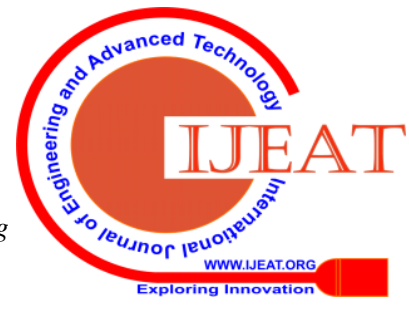


Table2: Test Results of Specimens

\begin{tabular}{|c|c|c|c|c|c|c|c|c|}
\hline $\begin{array}{c}\text { slab } \\
\text { ID }\end{array}$ & $\mathrm{F}_{\mathrm{cu}, \mathrm{cube}}$ & $\begin{array}{c}\mathrm{V}_{\mathrm{cr}} \\
\text { (ton) }\end{array}$ & $\begin{array}{c}\mathrm{V}_{\mathrm{u}, \mathrm{exp}} \\
\text { (ton) }\end{array}$ & $\bigoplus_{\mathrm{cu}} \%$ & $\vartheta_{\mathrm{su}} \%$ & $\begin{array}{c}\Delta_{\mathrm{y}} \\
(\mathrm{mm})\end{array}$ & $\begin{array}{c}\Delta_{\mathrm{u}, 0.85} \\
(\mathrm{~mm})\end{array}$ & $\begin{array}{c}\text { Mode of } \\
\text { failure }\end{array}$ \\
\hline S1 & 31.40 & 1.71 & 25.40 & 0.38 & 0.21 & 14.36 & 19.30 & $\begin{array}{c}\text { Punching } \\
\text { failure }\end{array}$ \\
\hline $\mathrm{S} 2$ & 30.60 & 2.45 & 29.00 & 0.32 & 0.25 & 4.26 & 14.67 & $\begin{array}{c}\text { Flexural } \\
\text { failure }\end{array}$ \\
\hline S3 & 32.10 & 3.05 & 31.95 & 0.33 & 0.27 & 3.41 & 14.00 & $\begin{array}{c}\text { Flexural } \\
\text { failure }\end{array}$ \\
\hline S4 & 31.60 & 2.01 & 31.22 & 0.33 & 0.26 & 4.73 & 16.35 & $\begin{array}{c}\text { Flexural } \\
\text { failure }\end{array}$ \\
\hline S5 & 30.90 & 2.35 & 33.79 & 0.31 & 0.29 & 4.75 & 19.00 & $\begin{array}{c}\text { Flexural } \\
\text { failure }\end{array}$ \\
\hline
\end{tabular}

Table3: Test Parameters of Specimens

\begin{tabular}{|c|c|c|c|}
\hline $\begin{array}{c}\text { Group } \\
\text { No. }\end{array}$ & Parameter Effect & Behavior study & Slab ID \\
\hline \multirow{2}{*}{ G1 } & \multirow{2}{*}{$\begin{array}{l}\text { Fiber Volume } \\
\text { Effect }\end{array}$} & $\begin{array}{c}\text { Group 1-1 } \\
\text { Shear punching behavior at slab column connection of Bottom Glass } \\
\text { Fiber mesh }\end{array}$ & $\begin{array}{l}\text { S1 } \\
\text { S2 } \\
\text { S3 }\end{array}$ \\
\hline & & $\begin{array}{l}\text { Group 1-2 } \\
\text { Shear punching behavior at slab column connection of Upper Glass } \\
\text { Fiber mesh }\end{array}$ & $\begin{array}{l}\text { S1 } \\
\text { S4 } \\
\text { S5 }\end{array}$ \\
\hline \multirow{2}{*}{ G2 } & \multirow{2}{*}{$\begin{array}{c}\text { Fiber Position } \\
\text { Effect }\end{array}$} & $\begin{array}{l}\text { Group 2-1 } \\
\text { Shear punching behavior at slab column connection of } 0.25 \% \text { Glass } \\
\text { Fiber mesh reinforcement }\end{array}$ & $\begin{array}{l}\text { S1 } \\
\text { S2 } \\
\text { S4 }\end{array}$ \\
\hline & & $\begin{array}{l}\text { Group 2-2 } \\
\text { Shear punching behavior at slab column connection of } 0.50 \% \text { Glass } \\
\text { Fiber mesh reinforcement }\end{array}$ & $\begin{array}{l}\text { S1 } \\
\text { S3 } \\
\text { S5 }\end{array}$ \\
\hline
\end{tabular}

\section{RESULTS DISCUSSION}

In general; the slab specimens (S2, S3, S4, and S5) were reinforcement by glass fiber mesh thin sheets with traditional steel bars reinforcement are failed in flexural and ductile modes of failure when it compared with slab specimen S1 without glass fiber mesh thin sheets, this attributed to the using of GFRP mesh sheets are resistant of cracks to propagate against punching shear.

Concrete and longitudinal deformed steel bars reinforcement strains were monitored, and its values are listed and summarized in table 2. The maximum concrete strain of specimen (S1) is $0.83 \%$, and the maximum tensile steel strain of (S1) was $0.21 \%$, while the maximum concrete strain ranged approximately from $(0.31-0.33 \%)$ and the maximum tensile steel strain was between $(0.255-0.29 \%)$ for slab specimens (S2, S3, S4, and S5). This prove that the slab specimens were reinforced with GFRP mesh sheet failed in flexural mode while slab specimen (S1) was failed in punching shear without steel yielding $(0.25 \%$; approximately).

Slab specimens, which were reinforced by GFRP mesh sheets, have a small average crack width and higher numbers of cracks compared with slab specimen without GFRP (S1). This refer to the glass fiber sheets as an extra reinforcement.

The abilities of slab specimens which was reinforced with mesh sheet of GFRP to resist the shear punching are higher than of slab specimen without GFRP sheet reinforcement this is attributed to the shear punching strength of flat plat specimens reinforced by GFRP mesh sheets was developed by considering the shear contribution of the concrete in compression zone and that of GFRP mesh sheets at the crack interface.

The results show that increasing in the failure of load capacity by $10.20 \%$ and $8.23 \%$ between (S2 and S3), and (S4 and S5); respectively as shown in figure 21, and 22. Increasing of the volume of GFRP mesh sheet leads to increasing of ductility by $19.50 \%$ and $15.60 \%$ between (S2 and S3), and (S4 and S5); respectively as shown in figure 25.

\section{Published By:}

Blue Eyes Intelligence Engineering \& Sciences Publication 


\section{Resistance of Flat Plate Reinforced of Glass Fiber Mesh Sheets Due To Shear Punching}

Slightly increasing in the failure of loads capacity between slab specimen which was laying of GFRP mesh sheet at compression zone (S4) and slab specimen which was laying of GFRP mesh sheet at tension zone (S2) by $7.70 \%$, as shown in figure 23. and Slightly increasing also in the failure of loads capacity between slab specimen which was laying of GFRP mesh sheet at compression zone (S5) and slab specimen which was laying of GFRP mesh sheet at tension zone (S3) by 5.80\%, as shown in figure 24 . propagation can be observed for all slab specimens, which were reinforced with GFRP mesh sheets.

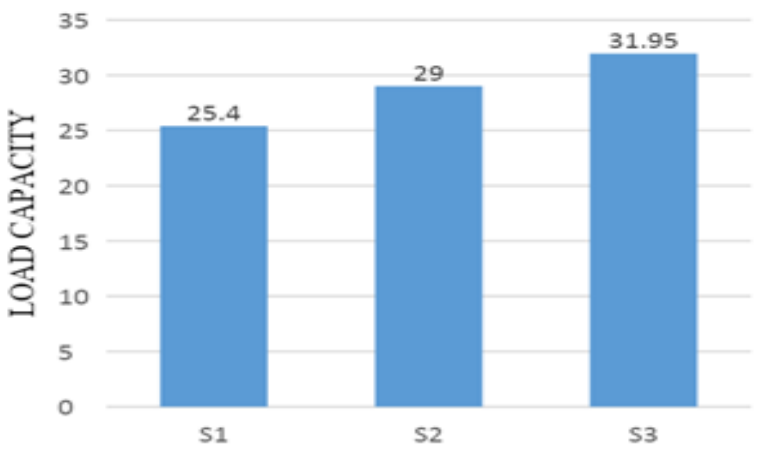

Figure 21: Load Capacity- Fiber Volume Relationship at Tension Zone

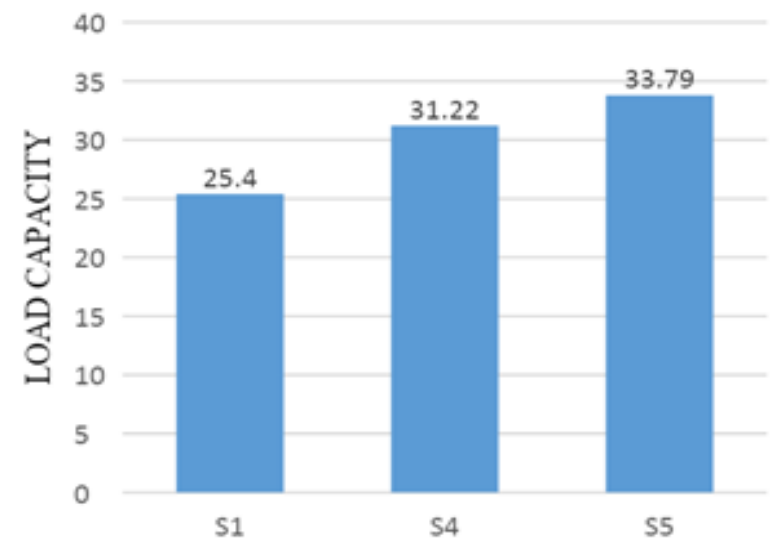

Figure 22: Load Capacity- Fiber Volume Relationship at compression zone

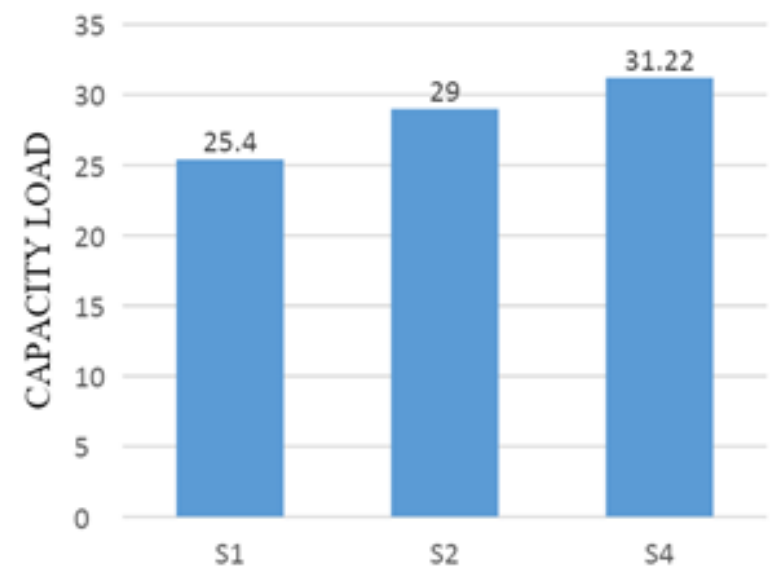

Figure 23: Load Capacity- Fiber Position Relationship
Same modes of failure, average crack width, and crack

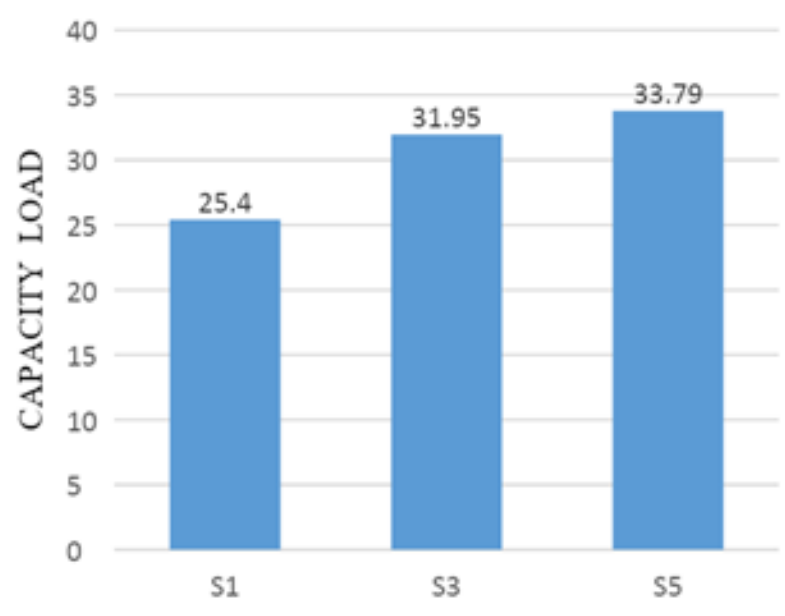

Figure 24: Load Capacity- Fiber Position Relationship

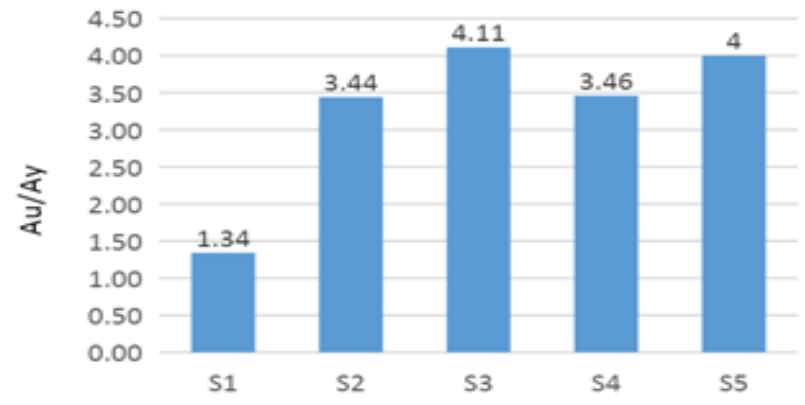

Figure 25: Ductility of Specimens

\section{SUMMARY AND CONCLUSIONS}

The following conclusions can be made according to previous analysis and discussion of the test results obtained from this research:

1- Using mesh sheets of GFRP in additional to traditional tension steel reinforcement leads to:

1.1 Increasing in failure load capacity up to $30 \%$.

1.2 Increasing in ductility by $206 \%$.

1.3Transforming a mode of failure from punching shear (brittle failure) to flexure (ductile failure).

2- Increasing in volume of GFRP mesh sheets leads to increasing in failure loads capacity up to $10.20 \%$.

3- Laying of GFRP mesh sheets in compression zone leads to increasing in punching shear resistant up to $7.70 \%$, and ductility up to $3 \%$ when it's compared with laying of GFRP mesh sheets in tension zone.

4- Using mesh sheets of glass fiber reinforced polymer in both tension zone or compression zone position led to decreasing in the deflection of flat plat reinforced concrete.

\section{REFERENCES}

1. ACI Committee 318, "Building code requirements for reinforced concrete and commentary", American Concrete Institute, Detroit 2008.

2. ACI 318, "Building code requirements for structural concrete and commentary", Farmington Hills, MI: American Concrete Institute (ACI), 2014

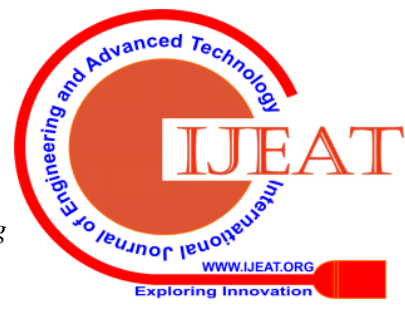


3. N. Banthia, M. Al-Asaly, and S. Ma, "Behavior of Concrete Slabs Reinforced with Fiber-Reinforced Plastic Grid”, Journal of Materials in Civil Engineering, 1995, pp 252-257.

4. BS EN 1992, "Design of concrete structures", General rules and rules for buildings, Brussels: European Committee for Standardization (CEN), Euro code 2, 2004, Part 1-1.

5. M.U. Bin, m. Christian, "Bending and Punching Shear Strength Of Fiber-Reinforced Glass Concrete Slabs", November 2002.

6. A.W. El-Ghandour, K. Pilakoutas, and P. Waldron, "Punching shear behavior of fiber reinforced polymers reinforced concrete flat slabs: experimental study", ASCE Journal of Composites for Construction, pp258-265.

7. ECP-203, "Egyptian Code of Practice for Design and Construction of Reinforced Concrete Structures" 2018.

8. Fib Model Code, "Fib Model Code for Concrete Structures", Lausanne, Switzerland, fib - International Federation for Structural Concrete, Verlag, Ernst and Sohn, 2013.

9. N. Gardner, J. Huh, and L. Chung, "Lessons from the Sampoong department store collapse", Cement and Concrete Composites, 2002, pp. 523-529.

10. J. Hedebratt, and J. Silfwerbrand, "Full-scale test of a pile supported steel

11. fibre concrete slab", Materials and Structures, 2014, pp. 647-666.

12. A. Hussein, M.I. Rashid, and B. Benmokrane, "Two-way concrete slabs reinforced with GFRP bars", Advanced Composite Materials in Bridges and Structures, In Proceeding of the 4th International Conference on Advanced Composite Materials in Bridges and Structures, CSCE, Calgary, Alta., Canada, July 2004, pp20-23.

13. J.H. Lee, Y.S. Yoon, and D. Mitchell, "Improving punching shear behavior of glass fiber reinforced polymer reinforced slabs", ACI Structural Journal, 2009, 106(4): pp427-434.

14. S. Matthys, and L. Taerwe, "Concrete slabs reinforced with FRP grids”, part II: Punching resistance. ASCE, Journal of Composites for Constructions, 2000, 4(3): pp154-161.

15. H. Mohamed, A.A. Ehab, B. Brahim, "Punching shear strength of glass fiber reinforced polymer reinforced concrete flat slabs", Article in Canadian Journal of Civil Engineering October 2013.

16. C.E. Ospina, S.D.B. Alexander, and J.J. Roger, "Punching of two-way concrete slabs with fiber-reinforced polymer reinforcing bars or grids", ACI Structural Journal, 2003, 100(5):pp589-598.

17. P. Ward, "SFRC suspended slabs in flexure", The Structural Engineer, 2010, pp. 16-19.

18. A. Zaghloul, and A. Razaqpur, "Punching shear strength of concrete flat plates reinforced with CFRP grids", Advanced Composite Materials in Bridges and Structures, In Proceeding of the 4th International Conference on Advanced Composite Materials in Bridges and Structures, CSCE, Calgary, Alta., Canada. 2004.

\section{AUTHOR PROFILE}

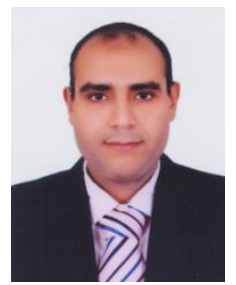

- $\quad$ Name: Mohamed S. Moawad.

- Job title: Structural lecturer in future high institute of engineering in fayoum.

- $\quad$ Date of Birth : $29 / 09 / 1983$

- $\quad$ Nationality: Egyptian.

- E-mail : m.moawad@fief.edu.eg

- $\quad$ Education Degree :

$\square$ Doctor of Philosophy, structural department, Cairo University, june-2016.

$\square$ Master degree, structural department, Cairo University, june-2010

$\square$ B.Sc., Civil Department, Cairo University, may 2005.

- Previous papers publications

Title: Behavior of corroded bonded Partially Prestressed Concrete beam, under review responsibility of Housing and Building National Research Center, 10 January 2016, HBRC Journal, ELSEVIER Publisher.

Title: Behavior of corroded bonded Fully Prestressed Concrete Beams, Peer review under responsibility of Housing and Building National Research Center, 10 January 2016, HBRC Journal, ELSEVIER Publisher.

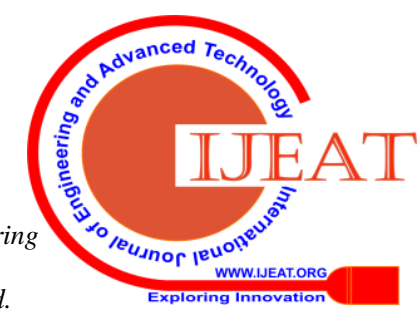

